Relations industrielles

Industrial Relations

\title{
Co-operative Values, Institutions and Free Riding in Australia
} Can It Learn from Canada?

Les valeurs coopératives, les institutions et le problème du resquillage en Australie Peut-on apprendre du Canada?

Valores cooperativos, instituciones y « beneficiarios libres » en Australia

\author{
¿Se puede aprender del Canadá?
}

\section{David Peetz}

Volume 60, numéro 4, automne 2005

La citoyenneté au travail ? Réflexions sur le milieu de travail de l'avenir

Citizenship at Work? Thinking the Workplace of the Future

¿La ciudadanía laboral? reflexiones sobre el medio laboral del futuro

URI : https://id.erudit.org/iderudit/012341ar

DOI : https://doi.org/10.7202/012341ar

Aller au sommaire du numéro

Éditeur(s)

Département des relations industrielles de l'Université Laval

ISSN

0034-379X (imprimé)

1703-8138 (numérique)

Découvrir la revue

Citer cet article

Peetz, D. (2005). Co-operative Values, Institutions and Free Riding in Australia: Can It Learn from Canada? Relations industrielles / Industrial Relations, 60(4), 709-736. https://doi.org/10.7202/012341ar

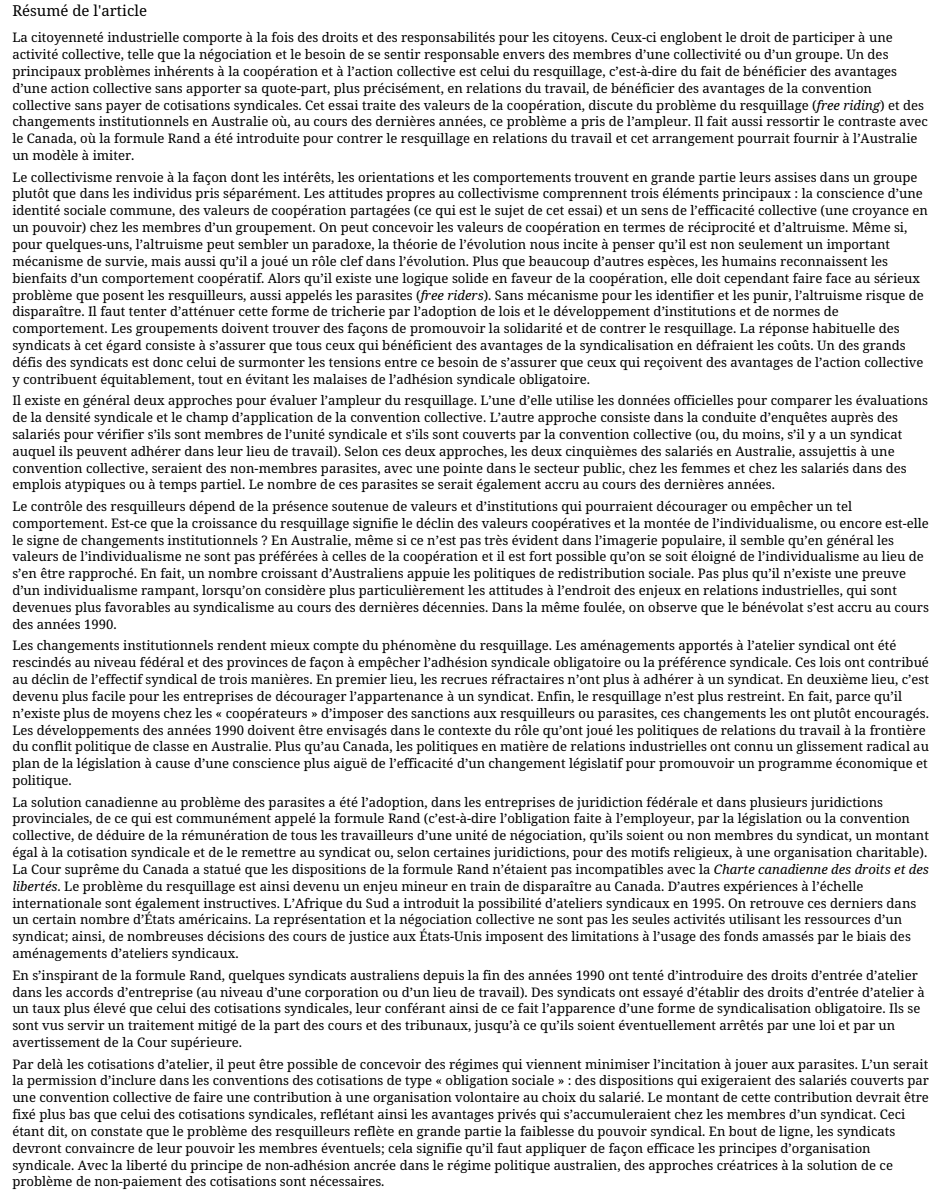
ollective sans payer de cotisations syndicales. Cet essai traite des valeurs de la coopération discute du problème du resquillage (free riding) et des Le Canada, où la formule Rand a été introduite pour contrer le resquillage en relations du travail et cet arrangement pourrait fournir à l'Australie

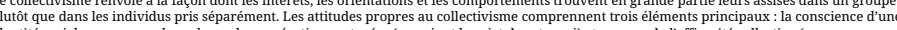

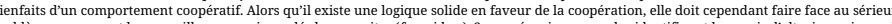
comportement. Les groupements doivent trouver des façons de promouvoir la solidarité et de contrer le resquillage. La réponse habituelle des nsyndicale obligatoire.

II existe en général deux approches pour évaluer l'ampleur du resquillage. L'une d'elle utilise les données officielles pour comparer les évaluations salariés pour vérifier s'ils sont membres de l'unité syndicale et s'ils sont couverts par la convention collective (ou, du moins, s'il y a un syndice

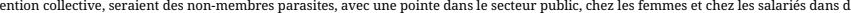
gage signifie le déclin des valeurs coopératives et la montée de l'individualisme, ou encore est-ell

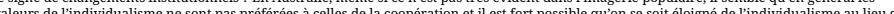
$s^{\prime}$ en être rapproché. En fait, un nombre croissant d'Australiens appuie les politiques de redistribution sociale. Pas plus qu'il n'existe une preuve devenues

quillage. Les an

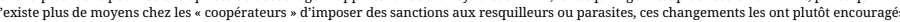
ments des années 1990 doivent être envisagés dans le contexte du rôle qu'ont joué les politicues de relations du travail à la frontière plan de la législation à cause d'une conscience plus aigué de le lefficacité d'un changement législatifi pour promouvoir un programme économique (a) bertés. Le problème du resquillage est ainsi devenu un enjeu mineur en train de disparaitre au Canada. D’autres expériences à l'échelle

En s'inspirant de la formule Rand quelques syndicats australiens depuis la fin des années 1990 ont tenté d'introduire des droits d'entrée d'atelier

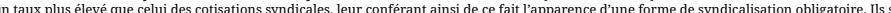
sont vus servir un traitement mitigé
avertissement de la Cour supérieure.

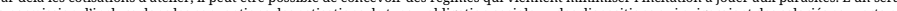

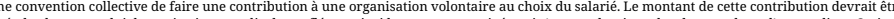
étant dit, on constate que le problemme des resquilleurs refletete en grande partie la faiblesse du pouvoir syndical. En bout de ligne, les syndicats problème dec la la najen du principe de non-adhésion an
Tous droits réservés (C) Département des relations industrielles de l'Université Laval, 2005
Ce document est protégé par la loi sur le droit d'auteur. L’utilisation des services d'Érudit (y compris la reproduction) est assujettie à sa politique d'utilisation que vous pouvez consulter en ligne.

https://apropos.erudit.org/fr/usagers/politique-dutilisation/ 


\title{
Co-operative Values, Institutions and Free Riding in Australia Can It Learn from Canada?
}

\section{David Peetz}

\begin{abstract}
While there is a strong logic favouring co-operation, it faces a central problem: the "free rider" or "cheat." Collectives find ways of promoting norms of solidarity and seek regulation to prevent free riding. Around two-fifths of Australian employees covered by collective agreements are free-riding non-members. Evidence suggests that the recent growth of free riding reflects institutional changes and not the decline of co-operative values and the ascendancy of individualism. The Canadian solution to the cheating problem, which is the Rand formula, inspired Australian unions to introduce (excessive) "agency fees" into collective agreements. These were eventually stopped by the state. Alternative models include "social obligation fees"-provisions for employees covered by the agreement to make a contribution to a voluntary organization of their choice.
\end{abstract}

Industrial citizenship implies both rights and responsibilities for citizens. These include the right to participate in collective activity such as bargaining, and the need to behave with responsibility towards fellow members of the collective or group. One of the central problems in co-operative, collective behaviour has been the problem of free riding. This article will consider co-operative values, free riding and institutional change in the context of Australia, where the incidence of free riding has increased in recent years. It will also examine the contrast with Canada, where the Rand model for dealing with the free-rider problem was introduced, and briefly provided a model for emulation in Australia. I start by introducing the general context of collectivism and identify where co-operative values (including reciprocity

- PeEtz, D., School of Industrial Relations, Griffith University, Brisbane, Australia, d.peetz@griffith.edu.au. 
and altruism) and free riding sit in a collectivist framework. I then look at the measurement of free riding and the general pattern of free riding in Australia. Consideration then turns to whether there is Australian evidence of a decline in co-operative values which might promote an increase in free riding, or whether institutional changes are responsible. I then look at how free riding has been dealt with or otherwise in the Canadian and Australian contexts, including some policy options for the future.

\section{COLLECTIVISM AND CO-OPERATIVE VALUES}

Collectivism refers to the way in which interests, orientations and behaviours are based on predominantly group rather than predominantly individual reference points. Collective interests, orientations and behaviours occur in all sorts of contexts: in community activities, in business, in politics, in industrial relations, in the home and family, even in nature. Before specifically discussing co-operative values, I will very briefly locate them in the context of a broader framework for thinking about collectivism (Peetz, 2006), which builds on various bodies of thought including mobilization theory (Kelly, 1998; Kelly and Badigannavar, 2004; Tilly, 1978), theories of efficacy (Bandura, 1997), social capital theory (Bourdieu, 1986; Putnam, 2000) and theories of the evolution of co-operation (Kropotkin, 1902; Sober and Wilson, 1998; Stewart, 2000). In order for collectivism to exist, there must be some collective needs or interest (Tilly, 1978)—needs that are common to a potential group and that therefore help define that group. These needs should be expressed across enough members of the group to generate a sense of common grievance (Gall et al., 2001). Second, for collectivism to flourish, there must be collectivist attitudes amongst potential members of the collective. These are constituted by an awareness amongst members of the group that they have something significant in common and that they have the capacity and intent to act co-operatively. Frege (1997) suggested six key dimensions to collectivist attitudes but these can be amalgamated to produce three main elements: awareness of a common social identity; shared co-operative values - the focus of this article; and a sense of collective efficacy (a belief in a group's power) amongst members of the group. Third, for collective actions to occur, the group must have a coordinating capacity (Lévesque and Murray, 2002), that is connections or networks between members of the group (Bourdieu, 1986; Putnam, 2000) and mobilizers (organizers) of those members (also referred to as "leaders" or "managers": Kelly, 1998; Stewart, 2000). These three elements lead to collective action. The collective power of the group is then a function of how this collective action is mediated by the institutional responses and environmental circumstances, that is by the behaviour of employers, 
governments, courts and tribunals, and the economy, which help shape the balance of power between the collective and individuals or groups with competing power.

\section{Co-operative Values: Reciprocity and Altruism}

Let us look more closely at co-operative values. We can think of them in terms of "reciprocity" and "altruism." In order for employees to behave co-operatively, they must at some stage be willing to experience a cost (or forego a benefit) in order to enable a benefit to apply to others. This may be in return for a direct benefit from someone else-this is "reciprocity." Alternatively, it may be for "altruistic" purposes, for some less specific gain-for example a benefit to a collective to which the individual belongs, and which the individual might or might not benefit from-or for some notion of the "greater good."

The mere existence of altruism is, for some, a puzzle because in crude evolutionary terms altruism should not exist. After Charles Darwin published On the Origin of the Species (1859) writers such as Thomas Huxley (1888) argued that biological evolution was based on advancement through competition between individuals of the same species. Later, Milton Friedman and others used this to argue that a free market economic system was natural as it was based on "survival of the fittest" (de Waal, 2000; Watkins, 1998). Altruism is a paradox for such writers because "an altruistic act ... decreases the fitness, that is, the chances of survival and reproduction of the actor, while increasing the fitness of a co-specific" (Krebs and May, 1976: 9, cited in Watkins, 1998). Eventually, altruism should have died out.

Yet recent and not-so-recent (Kropotkin, 1902) developments in evolutionary theory indicate that altruism is not only an important survival mechanism but has played a key role in evolution. Altruism is found, for example, in: numerous birds, squirrels and monkeys that call out to warn their colleagues that a predator is nearby (at the risk of being eaten themselves); fish, apes and feline and canine predators that collectively hunt; monkeys that collectively defend themselves against predators; vampire bats that share food with colleagues who have not eaten; and tropical fish, birds, bees and ants that forego the ability to breed in order to help feed and protect the progeny of others (Bshary, Wickler and Fricke, 2002; Dugatkin, 1997; Kibbins, 2002; Okasha, 2003; Stewart, 2000; Werner et al., 2003). Various evolutionary theories explain these behaviours, based on concepts of "kin selection" (promoting your relatives' progeny promotes genes that are similar to yours), "reciprocal altruism" (if you help someone who later helps you, the genes of both of you will be promoted), by-product mutualism 
(you eat by cleaning a big fish and he doesn't eat you) (Dugatkin, 1997; Okasha, 2003; Stewart, 2000) and, importantly, "group selection," whereby co-operative groups out-perform groups of selfish individuals (Sober and Wilson, 1998; Wynne-Edwards, 1993). There are scale benefits from cooperation: big co-operative groups also tend to out-perform smaller ones in nature (more food, fewer predators and easier raising of young) and the individuals in big groups have greater fitness than those in small groups (Clutton-Brock, 2002). An even more fundamental role for co-operation is given by Stewart (2000), who argues that all the great advances in evolution (bacteria into mitochondria, then single-celled animals into multi-celled animals, etc.) required co-operation. According to Stewart (2000: 7), "cooperators will inherit the earth!"

Humans recognize the benefits of co-operative behaviour-more than any other species (Boyd and Richerson, 2002). Ancient people came together to form villages and societies to take advantage of the benefits of co-operative living. Tradesmen came together to form guilds to protect their trades and conditions. Workers came together to form unions, as they could not meet their objectives (including to survive) as individuals acting alone. Individual capitalists, whose capacity to expand their wealth was restricted if they acted alone, came together to form limited liability corporations.

\section{Norms, Trust and the Free-rider Problem}

There is a strong logic favouring co-operation. However it faces a central problem: the "free rider" or "cheat." In nature, a monkey that refuses to warn the group of an impending predator has less chance of being eaten than one who does. A chimpanzee who expends no effort or risk while the other members of the group collectively hunt, but then has equal access to the bounty, would have better chance than the others of passing on his genes. An individual free rider within a group of altruists will obtain the benefits without any of the costs of group membership, and outperform the altruists. Without mechanisms for detecting and punishing free riders, the altruists would eventually die out. In the world of labour, non-unionists who free ride on the collective agreements won by unionists undermine the bargaining power of the collective, and strike breakers do so even more seriously.

Various behaviours necessarily emerge, then, to minimize cheating. These behaviours may be shaped by the development of laws and institutions, or the development of appropriate norms of behaviour. A common way in which free riding is suppressed in nature, and in human organization, is through the punishment of free riders (cheats) by co-operators. Depending on the context, union rules, group pressure and social isolation may punish individuals who cheat on employee collectives. 
Norms favouring co-operative behaviour are a key element of enabling altruism. Another key element is trust: "we are more comfortable cooperating with people who are likely to return any favours and to share the benefits of co-operation with us. So we co-operate more with family, friends and people we know we can trust" (Stewart, 2000: 26-7). The importance of trust is, in turn, reinforced through norms favouring trust and deploring cheating and free riding. The balance between norms and laws or institutions varies between cultures: Anglo-Celtic societies placed great emphasis on laws and regulations; Eastern societies placed great emphasis on the development of cultural norms that favoured reciprocity and co-operative behaviour. These "cultural" differences have been referred to in the psychological literature as representing competing "individualistic" and "collectivist" cultures (Hofstede, 1984). Nonetheless, even relatively "individualistic" societies such as the USA could not function in the absence of norms that promoted a significant degree of trust and co-operation.

Collectives find their own ways of promoting norms of solidarity, and regulation to prevent free riding. It becomes socially unacceptable to "bludge" (free ride) or "scab" (do the job of a striker). A considerable amount of union membership literature has been devoted to the free-riding problem (Booth, 1991; Cregan and Johnston, 1990; Crouch, 1982; Olson, 1965). For example, Olson (1965: 88) argues that an individualistic rational employee "will not voluntarily contribute to a union providing a collective benefit since he alone would not perceptibly strengthen the union, and since he would get the benefits of any union achievements whether or not he supported the union." There are partial responses available to unions. For example, they may try to restrict the improvements in wages arising from union gains through collective bargaining (or, in Australia, awards) to union members. While superficially attractive, it is potentially quite dangerous, since an increasing gap between union and nonunion wage costs also increases the incentive on employers to avoid unions, a significant factor in union decline in the US (Blanchflower and Freeman, 1992). Alternatively, unions may provide additional benefits that are only available to membersprotection against arbitrary discipline or unfair dismissal, and non-industrial services (in Australia, "Union Shopper"). While the former are important, the effects of market-competing services on union membership are disputed (Crouch, 1982; Kelly, 1990), with only work-related insurance (for example in regard to legal representation and unemployment and health insurance) significantly improving the propensity to join unions (Ben-Israel and Fisher, 1992; Peetz, 1998; Visser, 1991; Western, 1993). Exclusive protections help explain why free riding is not terminal for unions, but they do not prevent free riding on the major benefits unions achieve through collective bargaining. So, as with other groups, a very common way that unions have 
responded to the free-rider problem is to ensure all the beneficiaries of unionism pay the cost involved in obtaining it.

As the labour movements matured, unions in some countries (including Australia, New Zealand, Britain and the USA) used varying degrees of compulsory unionism as means of overcoming the free-rider problem. However, in large mature organizations compulsory unionism created its own pathologies. Unless the union had a strong workplace orientation, it tended to lead organizational leaders to become complacent, while (particularly in Australia and New Zealand) losing accountability to the workplace membership, with compulsory unionism in Australia being associated with poor responsiveness to member concerns, inadequate connections with members, low workplace voice, and falling satisfaction with their union (Bramble and Heal, 1997; Peetz, 1998; Zappala, 1992). Thus one of the challenges for unions is how to overcome the tension between needing to ensure that all beneficiaries of collective organization contribute equitably to the cost of it, while avoiding the pathologies associated with compulsory unionism.

\section{MEASURING FREE RIDING IN AUSTRALIA}

In industrial relations, free riders are people who obtain the benefits of collective agreements without paying the associated costs. Measuring free riding is not quite so simple. Broadly speaking, two approaches have been taken. One approach, using official data, is to compare estimates of union density and collective bargaining coverage: the difference between them represents the incidence of free riding, and the ratio of the difference to collective bargaining coverage is the free riding ratio, that is, the proportion of agreement-covered employees who do not belong to a union (Wilkinson, Harbridge and Walsh, 2003). The second approach is to survey employees and ascertain if they are union members and are covered by a collective agreement. A variant on this second approach is to ask if they are union members and there is a union at their workplace which they are eligible to join - an approach that has been used in New Zealand (Haynes and Boxall, 2004) where, at law, only union members can be covered by collective agreements, ${ }^{1}$ but in practice many employees on individual contracts in the same workplace enjoy exactly the same terms and conditions as are in the collective agreement covering their coworkers. This form of question has also been used in Australia (Teicher et al., 2006) though the institutional

1. This means that, in New Zealand, the use of official coverage data is becoming less meaningful over time for estimating free riding in New Zealand (Boxall and Haynes, 2004: footnote 2). 
framework (discussed below) is very different. Both methods have their limitations, so it makes sense to use data from each source to validate the other. The survey approach is reliant on employee perceptions and is generally subject to higher sampling errors because of resource constraints. It may overstate free riding if the denominator is all employees who have the opportunity to belong to a union, if their terms and conditions are not determined by a union agreement. The official coverage data approach assumes that all union members are covered by collective agreements, and that all collective agreements are union-negotiated. In Australia, neither of these assumptions are entirely valid.

At the time of writing, Australian employees could be covered by a range of instruments: (1) an award, an order issued by an arbitral tribunal that sets down minimum terms and conditions in an industry, occupation or enterprise; (2) a union collective agreement, negotiated by a union and registered under state or federal legislation; (3) a non-union "collective" enterprise agreement, in which a majority of employees at a workplace or enterprise vote in favour of an agreement and it is registered under what was s170LK of the federal Workplace Relations Act 1996 (WR Act); (4) an Australian Workplace Agreement (AWA), an individual contract also formalized under the WR Act; or (5) an unregistered individual contract, which might or might not have an award underpinning it. At law, the minimum value to workers of the pay and conditions in collective agreements and individual arrangements was determined by the net value of awards, through the operation of a requirement known as the "no disadvantage test." In mid 2004, 20 per cent of employees were covered by awards, approximately 36 per cent were covered by union collective agreements, another 2 per cent by collective agreements that were unregistered but would generally be presumed to be union agreements, 3 per cent by s170LK non-union enterprise agreements, 2 per cent by AWAs and 31 per cent by unregistered individual contracts. (The remaining 5 per cent were owner-managers of incorporated enterprises.) (ABS, Cat. No. 6306.0; Peetz, 2006). Unfortunately, the Australian Bureau of Statistics (ABS) does not distinguish between union and non-union collective agreements. In addition, while most union members are covered by enterprise agreements, a small proportion are reliant on awards or other instruments.

There are also some conceptual issues in assessing free riding. What if a non-member thinks that the benefits of union membership are not worth the cost? Is he free riding? What if a non-member does not believe in unions? Is he free riding? Drawing on Sobel (1995), Haynes and Boxall (2004) distinguish between "technical free riders," who may be in a position to join a union but do not, and "calculating free riders," who are motivated at least in part by a desire to obtain a benefit without paying a cost. The 


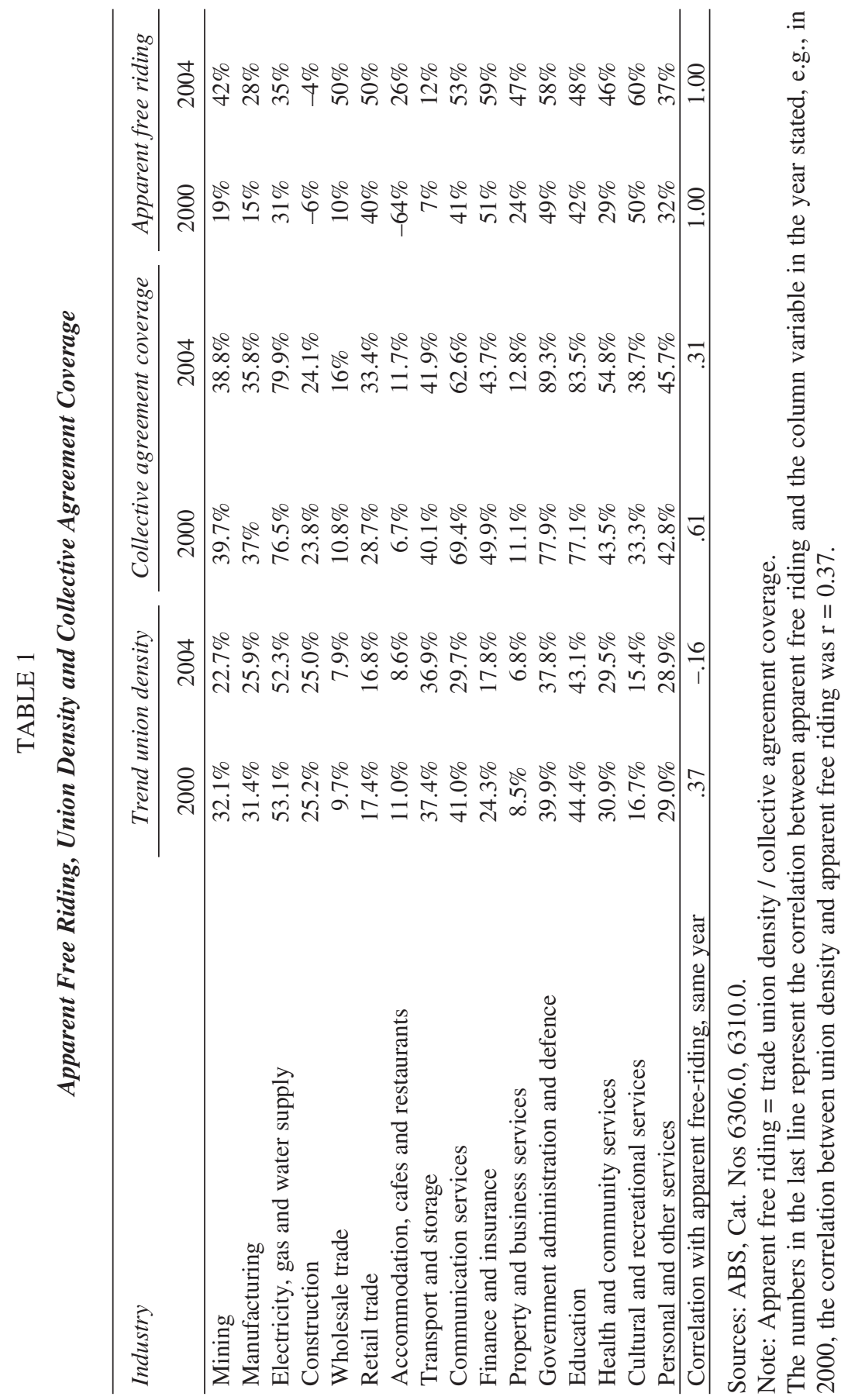


approach taken here, however, is simpler. Even with this distinction, both groups free ride in obtaining a benefit without paying a cost.

\section{The Magnitude of Free Riding in Australia}

A survey-based estimate of free riding in Australia comes from a telephone survey of 1000 employees in 2003-04 undertaken by Teicher et al. (2006). It showed that 39 per cent of workers who could be represented by a union that had a presence in their workplace were not themselves union members. When these non-members were asked to give a reason or reasons why they did not belong to a union, 52 per cent agreed that, amongst other reasons they may have given, they saw no point in joining "because I get all the benefits anyway." Some of these free riders also gave other justifications, for example union fees were too high or people doing their type of job did not usually join a union, but they were still obtaining many of the benefits of union membership without paying the costs (Teicher et al., 2006).

Estimates from coverage data show surprisingly similar results. After deducting section 170LK agreements, ABS data from 2004 implied that approximately 35.6 per cent of employees gained the benefits of registered union-negotiated agreements (ABS, Cat. No. 6306.0). Trend analysis (to minimize the effects of sampling variability) of ABS union membership data from the same year show that only about 22.8 per cent of employees were members (ABS, Cat. No. 6310.0; Peetz, 2005). The gap-what can be called net free riding - is equivalent to 12.8 per cent of employees, or 36 per cent of those covered by registered union collective agreements. When we take account of the fact that there are some union members who do not have collective agreement coverage (for example, in hospitality, construction and wholesaling), and some others are employees covered by unregistered union collective agreements, it is likely that close to two-fifths of workers gaining the benefits of union-negotiated collective agreements are not union members. This is comparable to the estimate from the survey by Teicher et al. (2006).

Net free riding has been increasing in Australia. Collective bargaining coverage has been rising while union coverage is falling. Between 2000 and 2004, in trend terms the proportion of employees who were union members fell from 24.8 per cent to 22.8 per cent, while estimated union registered collective agreement coverage rose from 33.2 per cent to 35.6 per cent. By implication, the minimum number of non-members gaining the benefits of union agreements rose quite substantially from 25 to 36 per cent of employees under union collective agreements.

Data on employee coverage of non-union "collective" agreements by industry are not published, so to have a more disaggregated look at 
free riding using coverage data we are forced to resort to "apparent free riding," which includes non-union agreements in the denominator. This overstates net free riding by an average of 4 to 5 percentage points, and probably leads to exaggeration of inter-industry variation in free riding, as the number of s170LK agreements is proportionately higher in industries with lower collective bargaining coverage (calculated from DEWR/OEA 2004 and ABS, Cat. No. 6306.0). That said, the extent of inter-industry variation in apparent free riding, shown in Table 1, suggests that industryspecific factors make a difference. In both 2000 and 2004 (and in 2002, not shown) free riding was higher in industries with higher collective agreement coverage, a finding consistent with the New Zealand experience using coverage data (Wilkinson, Harbridge and Walsh, 2003). It appeared to be worst in several predominantly public sector industries-government administration and defence, education, communication services-as well as in finance and insurance (where it is highest), culture and recreation, and retailing. Indeed, in the public sector as a whole apparent free riding in 2004 was 50 per cent, compared to 36 per cent in the private sector. On the other hand, the table suggests that the relationship between free riding and union density appears to be unstable, depending on the year for which data were observed, a pattern also having some similarity with New Zealand's (Wilkinson, Harbridge and Walsh, 2003).

In some low-coverage industries the number of union members was actually greater than the number covered by agreements, indicating that many union members in weakly organized industries (often with small workplaces) were unable to negotiate collective agreements. In the highly casualized hospitality industry (accommodation, cafes and restaurants) where unions have low density and difficulty negotiating collective agreements, in 2000 at least two-fifths of union members did not have collective agreement coverage. Many childcare workers would be in a similar situation. In construction, where about one in six union members are not covered by a collective agreement, a different explanation is likely. Here "negative free riding" probably reflects the project-based nature of the industry: near 100 per cent unionization rates prevail on many larger project sites, while some union members between large project jobs will find themselves working on smaller project sites that lack EBA coverage. In other industries there would also have been union members without agreement coverage, but their numbers were fewer than those of the free riders. Apparent free riding increased in all industries, but the increase was higher in the industries with lower density and lower collective bargaining coverage, suggesting that growth in free riding was associated with union weakness, and perhaps a low sense of collective efficacy. Supporting this, 49 per cent of technical free riders in the survey by Teicher et al. (2006) gave, as a reason for non-membership, that the union does not achieve anything they value. 
Apparent free riding amongst casuals was very high, at 71 per cent in 2004, reflecting the difficulties unions have in recruiting casual employees. Driven principally by the relationships between casualization, part-time employment and gender, apparent free riding was 58 per cent among part-time employees and 50 per cent amongst women.

Overall, it would appear that almost two-fifths of Australian employees covered by collective agreements "free ride." The growth of free riding also has a longer term dimension. Up until the 1990s, the main basis for wage determination in Australia was awards of tribunals (often supplemented by local, informal collective agreements). Awards were only made and maintained in response to application and effective advocacy from unions (with, from time to time, supportive industrial action). Without unions, workers would not have received the benefits of awards. In 1990, 80 per cent of employees were covered by awards; 41 per cent belonged to a union. In 2004, 60 per cent of employees were covered by awards or collective agreements underpinned by awards (and another indeterminate number were on individual contracts underpinned by awards) but only 23 per cent belonged to a union. Free riding on union-driven awards rose from 49 per cent to at least 62 per cent.

\section{CO-OPERATIVE VALUES IN DECLINE?}

The containment of free riding depends on the maintenance of values and institutions that discourage or preclude it, so does the growth of free riding represent the decline of co-operative values and the ascendancy of individualism? Or does it reflect institutional changes? The Business Council of Australia (BCA), a decade and a half ago, claimed that Australians needed to adjust their thinking about public policy because employee values and preferences had shifted away from collectivism to an individualistic framework (BCA, 1989). So let us consider the evidence. An influential argument implying the decline of co-operative values was made by Robert Putnam (2000) who looked at US opinion poll data on "social trust" (and other indicators of "social capital") over several decades. Since then he has observed a sharp reversal of most of the trends he previously described following the events of 11 September 2001 (Putnam, 2002). That aside, it is far from clear that Putnam's American results could be generalized to other industrialized nations. For example, "Canadians continue to manifest a spirit of social solidarity and commitment to social spending and programmes that is very high" (Mendelsohn, 2002: 32).

In Australia, evidence on popular ideology is mixed but overall suggests that, at a broad level, individualistic values are not inherently favoured over co-operative values and, if anything, the shift has been away from, not 
towards individualism, with increasing numbers of Australians supporting redistributive social policies (Peetz and Murray, 2003). In 1979 a major national survey found that, given a choice, 59 per cent of Australians thought that government should reduce taxes, whereas only 36 per cent thought it should spend more on social services - a gap of 23 percentage points (Aitkin, 1982: 385). Over two decades later, a directly comparable survey showed the gap had disappeared - only 35 per cent favoured cutting taxes, while slightly more people, 37 per cent, favoured spending more on social services (AES, 2001; see also Wilson and Breusch, 2003). When the wording of the question is amended slightly to give an example of what is meant - to give a choice between "reducing personal income taxes or increasing social spending on services like health and education" the margin is 48 per cent in favour of more social spending and just 28 per cent in favour of lower taxes (AuSSA, 2003). These data represented the opposite of a shift away from altruistic towards individualist sentiments- $\mathrm{a}$ particularly notable finding when you consider that taxes were higher in 2001 than in 1979 (ABS, Cat. No. 5506.0).

Surveys have also indicated widespread disquiet about the declining sense of social solidarity shown in trends in the distribution of income. A Newspoll survey showed that 83 per cent of Australians agreed (just 13 per cent disagreed) that the rich are getting richer and the poor are getting poorer, and while 55 per cent of Australians thought the distribution of wealth across Australian society had become less fair, just 10 per cent thought it had become more fair. Nor was this warranted by any economic payoff: given two options, 70 per cent said they would rather the gap between the rich and the poor get smaller, only 28 per cent preferred the overall wealth of Australia to grow as fast as possible (Newspoll, 2000). Between 1987 and 2004, the proportion of surveyed Australians who agreed that income and wealth should be redistributed to ordinary people rose from 46 per cent to 51 per cent, while the proportion disagreeing fell from 34 per cent to 20 per cent (McAllister and Mughan, 1987; AES, 2004). People who favour redistributive policies are more likely to support collective organization of workers (Deery and De Cieri, 1991; Grimes, 1994; Peetz, 1998).

Finally, as a general philosophy, Australians show a strong leaning towards collectivist rather than individualistic objectives: in the 2001 study 58 per cent agreed that Australia should be "a unified body pursuing a common goal," while just 19 per cent thought it should be a "collection of people independently pursuing their own goals" (AES, 2001). Similarly, in 2003 only 30 per cent favoured the statement "living standards in Australia would be best improved if each individual looked after his or her own interests first" while 49 per cent preferred the opposite view: "living standards 
in Australia would be best improved if we looked after the community's interests first" (AuSSA, 2003).

The data do not support the view that, in general, individualistic attitudes are increasingly swamping co-operative ones. Nor is the evidence of any shift to individualism any more convincing if we look specifically at attitudes towards industrial relations issues. In 1996, before the introduction of AWAs, 34 per cent of Australians agreed that individual contracts were better than enterprise agreements, while 30 per cent disagreed (AES, 1996). Seven years later attitudes were not so rosy. Although a majority said that "employees and employers should be able to negotiate pay and conditions directly," this did not translate into support for individual contracts, as 46 per cent agreed that "individual contracts favour the employer over the employee" while only 18 per cent disagreed. Some 43 per cent agreed that "employees will never protect their working conditions and wages without strong unions," while just 32 per cent disagreed, and 66 per cent agreed that "award wages are the best way of paying workers and setting conditions," with only 13 per cent disagreeing (AuSSA, 2003). Since the 1980s, attitudes have become steadily more pro-union, when measured by responses to such questions as whether unions: have too much power; have been a good thing for the country; should be subject to tighter controls; are doing a good job; or have trustworthy leaders. For example, the proportion of Australians saying unions were doing a "fairly good," "very good" or "excellent" job rose gradually from around 35 per cent in the mid 1980s to 50 per cent in the mid 1990s (Peetz, 1998). Newspoll data also show attitudes to unions becoming more favourable between 1996 and 2004, with half of workers now preferring to belong to a union than not belong (Bearfield, 2003; Robertson, 2005). Australian values on work-related matters are becoming more collectivist, not less. Similarly in 2002 in the USA, for the first time since the data were collected, more than half of non-unionists would vote for a union in a certification ballot if given the chance (Freeman, 2005).

In substance, then, the evidence suggests that values have not swung towards individualism. Similarly, both ABS data and data from time-use surveys show that volunteering behaviour in Australia increased through the 1990s (ABS Cat. No. 4441.0; Patulny, 2004: 16; Wilkinson and Bittman, 2002). Co-operation has been a core feature of evolutionary and social advance. It relies upon the prevention of cheating and the promotion of norms that promote altruistic behaviour. In general there is no evidence of any decline in co-operative norms. Indeed, general social attitudes are becoming more favourable towards progressive co-operative behaviour. This is clearly the case in employment relations, where attitudes are becoming more pro-union. Trends in volunteering behaviour also suggest the continuing strength of altruistic norms. To explain the growth in free riding we have to look elsewhere. 


\section{INSTITUTIONAL CHANGES IN AUSTRALIA}

Let us turn to institutional changes. Through most of the twentieth century, Australia had a tribunal-centred collectivist model in which key decisions regarding wages and employment conditions were made by industrial tribunals in formal settlement of unresolved industrial disputes. In the 1990s public policy sought to change the nature of arbitration-in particular, preventing the federal tribunal from arbitrating in interest disputes. Changes under a federal Labor Government to the wage system in the early 1990s, through the shift to "enterprise bargaining," sought to move wage fixing from a tribunal-centred collective model to a bargaining-centred collective model at the state and federal levels. Subsequently the conservative government's Workplace Relations Act 1996 emphasized a model that lacked both tribunals and collectivism. Arbitration now has a much narrower role than at any time over the preceding century. Union security arrangements have been rescinded at state and federal levels to prevent compulsory unionism or union preference. Regulation was changed at state and federal levels to permit non-union group agreement making and individual contracting. In the 1990s, governments passed laws in the Australian states (in order: New South Wales, Victoria, Western Australia, South Australia, Tasmania and Queensland) and in the federal jurisdiction (which covered 40 per cent of workers) that prohibited compulsory membership of unions and promoted non-union "bargaining" including individual contracting. These laws contributed to the drop in union membership in three ways. First, unwilling conscripts no longer had to belong to a union. Second, it became easier for corporations to discourage union membership. Third, free riding was no longer constrained. Indeed, because there was no way that co-operators could impose sanctions on free riders, these changes actively encouraged free riding. Union density fell-most rapidly in those states that had recently introduced these changes - and free riding grew. These were not the only factors in union decline: other important factors were structural changes in the labour market, a change in strategies by employers towards unions (aimed in part at removing compulsory unionism), and union weakness at the workplace level (Peetz, 1998). Nonetheless, the impacts of institutional changes on unionism and free riding were real and substantial.

The developments of the 1990s need to be seen in the context of the role industrial relations policy has played at the frontier of class political struggle in Australia. More so than in Canada, industrial relations policy in Australia has been subject to radical shifts in legislation as a result of a greater sense of the efficacy of changing legislation. This in turn probably reflects several factors: the greater centralization of processes and outcomes due to the existence of the award system and the importance of the federal 
jurisdiction, meaning that institutional changes have a bigger impact on workplace practice; the absence of an Australian equivalent of Quebec, meaning less priority is given to issues of national unity and to avoiding nationally divisive policies, as there is no real fear of the federation breaking apart; and the strongly class-based nature of Australian political parties, meaning that for conservative parties an attack on trade unionism is also an attack on their political opponents.

\section{CANADIAN SOLUTIONS}

The Canadian solution to the cheating problem is the Rand formula, which applies in the federal jurisdiction and some provincial jurisdictions. The Rand formula (named after a chief justice who settled a pivotal strike in the automobile industry in 1945-46) provides for non-unionists in a unionized workplace to pay the equivalent of dues to the union. The original strike concerned a union claim for a closed-shop provision in a proposed agreement, in the context of concern that the employer would use the flood of returning ex-servicemen to deunionize the company. The employer strongly resisted, claiming the employer's right to hire and fire would be handed over to the union. The bitter and expensive strike was settled by arbitration. Rand, CJ determined that union should not be endowed with the power to shape hiring policies, but that it was desirable for a stable industrial relations system for unions to have security once recognized. The Rand formula dealt with the free-rider problem and gave unions security of income, and in turn required unions to uphold the terms of the collective contract. Support for or acquiescence to illegal strikes (which up until then had been a common feature of Canadian industrial relations) could lead to the arrangement being withdrawn. In 1948, the federal Industrial Relations and Disputes Investigation Act was introduced to, inter alia, permit agreements to deal with union security issues (Russell, 1990: 220-230). In 1951, about 19 percent of unionized employees in Canadian manufacturing were covered by the Rand formula. By 1991, 43 per cent of all Canadian employees in workplaces with 500 or more employees were covered by Rand, with another 45 per cent covered by other union security provisions such as union shops (Russell, 1990 and pers. comm.).

As the Rand formula spread through the Canadian system the incidence of illegal strikes declined (Russell, 1990). Following a 1968 report of a Task Force on Industrial Relations (the Woods Report), the federal laws were changed to give explicit recognition to the Rand formula as a bargaining item. In 1984 further amendments made the Rand formula in effect mandatory in the federal jurisdiction. Several provincial jurisdictions also require Rand clauses in all collective agreements, including Ontario, 
Quebec, British Columbia, Manitoba, Saskatchewan and Newfoundland (Akyeampong, 2000: 38; Arthurs et al., 1993: 247). In most of these, employees can seek exemption where they have religious objections to joining a union or paying regular union dues, provided they pay an equivalent amount to an agreed charity (s. 1 of the Canadian Federal Labour Code). If the employee and union cannot agree on a charity, the Labour Relations Board can nominate one. Sincere but non-religious convictions are not adequate to obtain this exemption. In other provincial jurisdictions, unions can negotiate Rand provisions but they are not mandated, though employers must provide automatic dues check-off where requested by the union (Arthurs et al., 1993: 248). The Supreme Court of Canada in 1991 determined that Rand-formula provisions were not inconsistent with guarantees of freedom of association set out in the Charter of Rights and Freedoms. ${ }^{2}$ Free riding is a minor and declining issue in Canada, with net free riding (based on official coverage data) falling from 9 per cent to 7 per cent between 1997 and 1999 (Akyeampong, 2000: 37).

Canada is not alone in its use of this system, also referred to as "agency shops." South Africa introduced the capacity for agency shops in 1995 (Orr, 2001). They have been used in a number of American states. Collective bargaining and representation are not the only use to which union resources are put, and so various US court cases have placed limitations on what funds raised through agency shop arrangements can be used for (Orr, 2001). Some US states have legislated to set a ceiling to the level of fees that can be charged - for example, at around 85 per cent of union dues in New Jersey and Minnesota public employment (Ali Raza and Anderson, 1996, cited in Orr, 2001). Some New Zealand unions, which act for non-members as a bargaining agent on a fee-for-service basis, charge an amount for this that is substantially less than normal union membership dues. In Canada, though, agency fees are essentially set at the level of union fees.

\section{AUSTRALIAN APPLICATION?}

Taking their inspiration from the Rand formula, from the late 1990s some Australian unions sought to introduce "agency fees" or "bargaining services fees" into enterprise agreements. Under agreements with such clauses, employees who were not union members were required to pay a fee to the union that negotiated the agreement by which they were covered. One of the notable features was that several Australian unions sought to go

2. Lavigne v. Ontario Public Service Employees Union, [1991] 2 S.C.R. 211, cited in Arthurs et al. (1993: 247). 
well beyond the Canadian provisions, by charging an agency fee that was higher than the annual union fee (Lee, 2004).

In Australia, a portion of union fees fund other activities that are more concerned with providing protection or benefits for individual union members (in relation to grievances, unfair dismissal, insurance, etc.). Indeed, protective services such as these, where free riding is not possible, are often the most common reason people give for belonging to a union (Gallagher and Strauss, 1991; Millward, 1990; Van de Vall, 1970). The claim could therefore easily and correctly be made that a requirement that non-members pay a fee equal to union dues would represent a cross-subsidy from nonmembers to members. A higher fee would arguably represent a form of de facto compulsory unionism. While the primary rationale is to prevent free riding, through the cross-subsidy by union members of non-members, there are also arguments that fees should not be so high as to create a reverse cross-subsidy. Moreover, excessive bargaining fees would encourage inertia on the part of unions, by reducing or removing the incentive to recruit members and to provide adequate support for members in workplaces with agreements - the pathologies of compulsory unionism. It would encourage what Stewart (2000), in an evolutionary context, refers to as "exploitation" of the group by its "managers." This suggests that it is desirable that there be a discount applied against the union dues in calculating an agency fee, as applied in some American states. This would also avoid expectations by non-members paying agency fees that the union would represent them in non-bargaining contexts. On the other hand, the costs incurred by members in obtaining favourable collective agreements often go beyond the fees they pay, and may include lost income during industrial conflict. This suggests that any discount in agency fees should not be too large. For Australian unions, however, the idea of a discount was irrelevant as they instead sought to charge a premium. Agency fees thus had the appearance of being a de facto form of compulsory unionism, and were subject to much criticism.

Agency fees received ambivalent treatment from state and federal tribunals (O'Neill and Shepherd, 2003; Lee, 2004). The Australian Industrial Relations Commission (AIRC) initially approved agreements containing an agency fee charged by the Communications, Electrical and Plumbing Union (CEPU) and set above the relevant union fees, despite intervention to oppose it by a government agency. ${ }^{3}$ This decision was upheld by a full bench of the AIRC, though it raised questions about whether agency fees pertained to the employment relationship, to which enterprise agreements,

3. Re: Accurate Factory Maintenance Labour Hire Enterprise Agreement 2000-2003, McIntyre VP, AIRC, 9 February 2001, PR900919. 
under federal legislation, were restricted. ${ }^{4}$ Later, when the Federal Court considered whether an agency fee validly pertained to the employment relationship (for the purposes of enabling immunity from civil action during industrial action to secure a new collective agreement), the court concluded that it did not. ${ }^{5}$ Meanwhile the federal government had attempted to change the WR Act in 2001 to prohibit agency fees, but was frustrated by the Senate, where the party holding the balance of power, the Australian Democrats, expressed their support for both "fee-for-service" and freedom of association (Murray, 2001). In 2003, however, the Democrats reversed their position and allowed passage of the Commonwealth Workplace Relations Amendment (Prohibition of Compulsory Union Fees) Act 2003, which rendered agency fees invalid and prohibited their further use in the federal jurisdiction. The passage of this legislation by the Senate (which had rejected most other conservative industrial relations legislation from 1997 to 2004) was encouraged by the high level at which agency fees were being set. Some state tribunals, however, continued to permit agency fees in certain circumstances, including an agreement that allowed a bargaining fee set at 80 per cent of the union fee to be charged (originally rejected because it set the agency fee at the same rate as the union membership fee). ${ }^{6}$ In late 2004, the status of bargaining fees in the federal jurisdiction was definitively dealt with in the Electrolux case by the High Court, which ruled they were invalid because they were not directly relevant to the employment relationship. At the time of writing, the federal government had introduced legislation to override state tribunals' capacity to allow bargaining fees.

\section{CONCLUDING REMARKS}

A co-operative animal community in which around two-fifths of members were free riding on the work of the other three-fifths would be in serious trouble. The number of cheats would grow at the expense of co-operators until eventually co-operation stopped and the animal group collapsed. For unions, the problem can be lessened by providing selective benefits that are only available to union members, for example, represen-

4. Re: Accurate Factory Maintenance Labour Hire Enterprise Agreement 2000-2003 and other Agreements, AIRC, Print PR 910205, 12 October 2001.

5. Electrolux Home Products Pty Ltd v. Australian Workers Union [2001] FCA 1600 (14 November).

6. Ian Gregory Morrison Pty Ltd (SA) Patrol and Security Officers Enterprise Agreement 2002-2004 (No 2) - Bargaining Agents Fee [2004] SAIRComm 15 (14 April).

7. Electrolux Home Products Pty Ltd v. Australian Workers' Union [2004] HCA 40 (2 September). 
tation in disciplinary or unfair dismissal situations. However, while nonmembers are able to gain the benefits of collective bargaining (which is, after all, the principal means of operation of unions) at no cost, free riding represents a significant danger for unions, with each new free rider directly weakening the bargaining strength of the remaining co-operators.

The growth of free riding in Australia is therefore a major problem for unions and for collective behaviour. It does not seem, however, that the growth of free riding reflects any decline in co-operative values. If anything, co-operative values have strengthened, particularly in regard to employment relations. Rather, changing institutional factors appear to be the culprits. Legislation and employers that are more antagonistic towards unions have removed the barriers to punishing cheats and promoted free riding. An effective public policy response to cheating has been developed in Canada. This is not the case in Australia, and more innovative changes in public policy and union practice, building on the concept of social obligation, may be necessary to reduce the problem of cheating and promote good citizenship amongst the industrial citizens.

Beyond agency fees, it may be possible to develop alternative models which minimize the incentive to free ride. One would be to permit the inclusion in agreements of "social obligation fees"-provisions which required employees covered by the agreement to make a contribution to a voluntary organization of the employees' choice. These would be roughly analogous to the charity exemption allowed for conscientious objectors to the Rand levy (and to conscientious objectors to union membership in the Australian federal jurisdiction in earlier decades), but importantly there would be no requirement to prove conscientious objection, merely an instruction as to where employees' social obligation fees should be directed. That recipient organization could be a trade union to which the employee belonged (in which case it would represent a credit towards their union fee) or a charity or other voluntary association. The level of contribution should be set at a rate lower that union fees, reflecting the private benefits accruing to union members (the benchmark of roughly 80 per cent established in some state jurisdictions in the US and Australia would be a useful starting point for setting an appropriate rate). Unions would be able to waive the fee for members or credit it against membership fees. There would be no incentive on employees to free ride on union gains, but equally there would be no compulsion to join the union and employees who were philosophically opposed to joining a union or who were simply unhappy with union performance would be entirely free not to join or contribute to a union. Such provisions probably would be outside the scope of federal agreements as they would probably not be considered a matter for the employment relationship until federal legislation were changed (most likely 
by a government of different philosophical persuasion), but they would not fall foul of "freedom of association" principles.

That all said, there are limits to how far state policy can enable unions to deal with free riding. A close reading of the survey and coverage data suggest that part of the free-rider problem reflects beliefs that union power is inadequate to achieve the results potential members would want. In the end, for unions to secure significant growth in membership in workplaces where they have a union presence and collective agreement, they will need to persuade potential members of their power, and this comes down to effective application of organizing principles (Crosby, 2005; Kelly and Badigannavar, 2004; Lévesque and Murray, 2002). Only when they have the confidence of a strong majority of the workforce at a workplace would agency fees come into play as a viable approach for addressing free riding.

As in nature, the key issue for the prevention of cheating is to ensure that free riders do not gain from their cheating, either by enjoying the benefits of collective gains or by not experiencing the resource cost of contributing to the collective effort. Social obligation fees satisfy these requirements, while reducing the scope for "managers" to exploit the group over which they have control, instead requiring them to promote and coordinate co-operation amongst the members of the group to best advance the interests of those members (Stewart, 2000: 58). With freedom of "disassociation" principles entrenched in the Australian polity, creative approaches to resolving the free-rider problem are required.

\section{】 REFERENCES}

AITKIN, Don. 1982. Stability and Change in Australian Politics. $2^{\text {nd }}$ ed. Canberra: Australian National University Press.

AkyeAmpong, Ernest B. 2000. "Non-unionized but Covered by Collective Agreement." Perspectives on Labour and Income, 12 (3), Statistics Canada Catalogue No. 75-001-XPE, 33-59.

Arthurs, Harry W., Donald C. Carter, Judy Fudge, Harry J. Glasbeek and Gilles Trudeau. 1993. Labour Law and Industrial Relations in Canada. Deventer: Kluwer / Butterworths.

ABS (Australian Bureau of Statistics). Employee Earnings and Hours, Australia. Catalogue No. 6306.0, Canberra, variours years.

ABS (Australian Bureau of Statistics). Employee Earnings, Benefits and Trade Union Membership, Australia. Catalogue No. 6310.0, Canberra, various years.

ABS (Australian Bureau of Statistics). Taxation Revenue, Australia. Catalogue No. 5506.0, Canberra, various years.

ABS (Australian Bureau of Statistics). Voluntary Work, Australia.

Catalogue No. 4441.0, Canberra, various years. 
AES (Australian Election Study). 1996. Australian Election Study Computer File. (ASSDA No. DO 943). Canberra: Australian National University.

AES (Australian Election Study). 2001. User's Guide for the Machine Readable Data File. Australian Social Sciences Data Archive, Canberra: Australian National University.

AES (Australian Election Study). 2004. Australian Election Study 2004. Computer File. Canberra: Australian National University.

AuSSA (Australian Survey of Social Attitudes). 2003. Australian Survey of Social Attitudes. On-Line Computer File. Canberra: ACSPRI Centre for Social Research, Australian National University.

BAndurA, Albert. 1997. Self-Efficacy : The Exercise of Control. New York: W. H. Freeman \& Company.

BCA (Business COUNCIL OF Australia). 1989. Enterprise-based Bargaining Units: A Better Way of Working. Part 1, Melbourne: BCA.

BeArFiEld, Sue. 2003. Australian Employees' Attitudes towards Unions. Working Paper No. 82, ACIRRT, University of Sydney, Sydney, March.

Ben-Israel, G., and H. Fisher. 1992. "Trade Unions in the Future: Organizational Strategies in a Changing Environment." Trade Unionism in the Future. Ninth World Congress of International Industrial Relations Association, August, 85-97.

Blanchflower, David, and Richard B. Freeman. 1992. "Unionism in the US and Other Advanced OECD Countries." Industrial Relations, 31 (1), 56-79.

BоотH, Alison. 1991. "What Do Unions Do Now? A Study of the Provision by British Trade Unions of Benefits and Services to their Members." Labor Studies Journal, 16 (2), 50-64.

Bourdieu, Pierre. 1986. "The Forms of Capital." Handbook of Theory and Research for the Sociology of Education. J. G. Richards, ed. New York: Greenwood Press, 241-258.

Boyd, R., and P. J. Richerson. 2002. "Solving the Puzzle of Human Cooperation." Evolution and Culture. S. Levinson, ed. Cambridge, Mass.: MIT Press.

Bramble, Tom, and S. Heal. 1997. "Trade Unions." Political Economy of New Zealand Since 1945. B. Roper and C. Rudd, eds. Auckland: Oxford University Press, 119-140.

Bshary, R., W. WiCKLER and H. Fricke. 2002. "Fish Cognition: A Primate's Eye View." Animal Cognition, 5 (1), 1-13.

Clutton-Brock, T. 2002. "Behavioral Ecology-Breeding Together: Kin Selection and Mutualism in Cooperative Vertebrates." Science, 296 (5), 69-72.

Cregan, Christine, and S. Johnston. 1990. “An Industrial Relations Approach to the Free-Rider Problem: Young People and Trade Union Membership in the UK." British Journal of Industrial Relations, 28 (1), 84-104.

Crosby, Michael. 2005. Power at Work: Rebuilding the Australian Union Movement. Sydney: Federation Press. 
Crouch, Colin. 1982. Trade Unions: The Logic of Collective Action. London: Fontana.

DARwIN, Charles. [1859] 1936. On the Origin of the Species. New York: The Modern Library, http: //www.infidels.org/library/historical/charles_darwin/ origin_of_species/index.shtml.

DE WAAL, F. 2000. “Reading Nature's Tea Leaves.” Natural History, 109 (10), 66-71.

DeERY, Stephen, and Helen DE CIERI. 1991. "Determinants of Trade Union Membership in Australia." British Journal of Industrial Relations, 29 (1), 59-73.

Department of Employment and WorkPlace Relations And OfFice of the Employment Advocate. 2004. Agreement Making in Australia under the Workplace Relations Act, 2002 and 2003. Canberra: DEWR, June.

Dugatkin, L. A. 1997. "The Evolution of Cooperation." Bioscience, 47 (6), 355-362.

FreEman, Richard B. 2005. "Can Unions Close the Unfilled Demand for Representation and Participation in the US?" Unpublished paper, Harvard University and NBER.

Frege, Carola M. 1997. "Does Economic Transformation undermine Union Collectivism? The Case of East German Textile Workers." Industrial Relations Journal, 28 (3), 163-175.

Gall, G., P. Bain, K. Gilbert, G. Mulvey and P. Taylor. 2001. "Worker Mobilisation, Collectivism and Trade Unionism in Call Centres in Britain." Employment Research Unit $16^{\text {th }}$ Annual Conference, Cardiff University, Cardiff Business School, 10-11 September.

Gallagher, David, and George Strauss. 1991. "Union Membership Attitudes and Participation." The State of the Unions. G. Strauss, D. G. Gallagher and J. Fiorito, eds. Madison, Wisc.: Industrial Relations Research Association, 139-174.

Grimes, Paul F. M. 1994. "The Determinants of Trade Union Membership: Evidence from Two Australian Surveys." PhD thesis, Research School of Social Sciences, Australian National University, Canberra.

Haynes, Peter, and Peter Boxall. 2004. "Free Riding in New Zealand: Incidence, Motives and Policy Implications." Labour and Industry, 15 (2), 47-63.

Hofstede, G. 1984. Culture's Consequences: International Differences in Work-Related Values. London: Sage.

HuXley, Thomas H. 1888. "The Struggle for Existence in Human Society." Collected Essays, 9, 195-236.

Kelly, John. 1990. "British Trade Unionism 1979-89: Change, Continuity and Contradictions." Work, Employment and Society, Special issue, May, $29-60$.

Kelly, John. 1998. Rethinking Industrial Relations: Mobilization, Collectivism, and Long Waves. London, New York: Routledge. 
Kelly, John E., and V. Badigannavar. 2004. "Union Organizing." Union Organization and Activity: The Future of Trade Unions in Britain. J. Kelly and P. Willman, eds. London: Routledge, 32-50.

KIBBINS, G. 2002. "Be Nice or Die: Dinosaur and the Evolutionary Imperative." Journal of American and Comparative Cultures, 25 (3-4), 298-304.

Kropotkin, Petr Alekseevich. [1902] 1972. Mutual Aid: A Factor of Evolution. New York: New York University Press.

LEE, M. 2004. "Shaping a Preferred Bargaining Paradigm: Labour Law Remedies, the Scope of Agreements and Union Influence." New Economies: New Industrial Relations. Proceedings of the $18^{\text {th }}$ AIRAANZ Conference. Noosa: Association of Industrial Relations Academics of Australia and New Zealand, February, 293-302.

LÉvesque, Christian, and Gregor Murray. 2002. "Local Versus Global: Activating Local Union Power in the Global Economy." Labor Studies Journal, 27 (3), 39-65.

McAllister, I., and A. Mughan. 1987. Australian Election Survey 1987. Computer File (ASSDA No. 445). Canberra: The Australian National University.

Mendelsohn, M. 2002. Canada's Social Contract: Evidence from Public Opinion. Discussion Paper No. P/01, Ottawa: Canadian Policy Research Networks, November.

Millward, Neil. 1990. "The State of the Unions." Social Attitudes: The Seventh Report. R. Jowell, S. Witherspoon and L. Brook, eds. Aldershot: Gower, 27-50.

MurRAY, Andrew. 2001. "Australian Democrats Minority Report." Workplace Relations Amendment (Prohibition of Compulsory Union Fees) Bill 2001. Canberra: W. R. Senate Employment, Small Business and Education Committee, 21-22.

Newspoll. 2000. National Telephone Survey of 1200 Adults, 14-16 January. Sydney. http://newspoll.com.au/image_uploads/cgi-lib.13778.1.0101quality_ of_life.pdf..

OKasha, S. 2003. Biological Altruism. Summer. http://plato.stanford.edu/ archives/sum2003/entries/altruism-biological.

Olson, Mancur. 1965. The Logic of Collective Action: Public Goods and the Theory of Groups. Cambridge, Mass.: Harvard University Press.

O’NeILL, Steve, and Bronwen SHEPHERD. 2003. "Bargaining Fees and Workplace Agreements." Current Issues e-brief. Canberra: Parliamentary Library, http:// www.aph.gov.au/library/intguide/ECON/Bargaining_Fees.htm.

ORR, Graeme. 2001. "Agency Shops in Australia? Compulsory Bargaining Fees, Union (In)Security and the Rights of Free-Riders." Australian Journal of Labour Law, 14 (1), 1-35.

PATUlny, Roger. 2004. Social Capital and Welfare: Dependency or Division? Examining Bridging Trends by Welfare Regime, 1981 to 2000. SPRC Discussion Paper No. 138, Sydney: Social Policy Research Centre, University of New South Wales, February. 
PeEtz, David. 1998. Unions in a Contrary World: The Future of the Australian Trade Union Movement. Cambridge: Cambridge University Press.

PeEtz, David. 2005. "Trend Analysis of Union Membership." Australian Journal of Labour Economics, 8 (1).

PeEtz, David. 2006. Brave New Workplace: How Individual Contracts are Transforming our Jobs. Sydney: Allen \& Unwin.

PeEtz, David, and Georgina MurRay. 2003. "Popular and Elite Workplace Ideology and the Shift to Individualism." New Times, New Worlds, New Ideas: Sociology Today and Tomorrow. TASA 2003 Conference, Armidale: The Australian Sociological Association and University of New England, December.

Putnam, Robert D. 2000. Bowling Alone: The Collapse and Revival of American Community. New York: Simon and Schuster.

Putnam, Robert D. 2002. "Bowling Together: The United State of America." The American Prospect, 13 (3), 20-22.

Robertson, J. 2005. "State of the Union." Workers Online. April, http:// workers.labor.net.au/features/200504/b_tradeunion_auspoll.html

Russell, Bob. 1990. Back to Work? Labour, State and Industrial Relations in Canada. Scarborough, Ont.: Nelson.

Sobel, G. S. 1995. "Empirical Evidence on the Union Free-Rider Problem: Do Right-to-Work Laws Matter?" Journal of Labor Research, 16 (3), 347-365.

SoBER, Elliott, and David Sloan WILSON. 1998. Unto Others: The Evolution and Psychology of Unselfish Behavior. Cambridge, Mass.: Harvard University Press.

StEWART, John. 2000. Evolution's Arrow: The Direction of Evolution and the Future of Humanity. Canberra: Chapman Press.

Teicher, Julian, Amanda Pyman, Peter Holland and Brian Cooper. 2006. "Employee Voice in Australia." What Workers Say: Employee Voice in the Anglo-American World. R. B. Freeman, P. Boxall and P. Haynes, eds. Ithaca, N.Y.: ILR Press.

Tilly, Charles. 1978. From Mobilization to Revolution. New York: Random House.

VAn de Vall, M. 1970. Labor Organizations. Cambridge: Cambridge University Press.

VISSER, E. Jelle. 1991. "Trends in Trade Union Membership." Employment Outlook. Paris: Organization for Economic Cooperation and Development, 97-134.

WATKInS, John P. 1998. "Towards a Reconsideration of Social Evolution: Symbiosis and its Implications for Economics." Journal of Economic Issues, 32 (1), 87-105.

Werner, Noam Y., Sigal Balshine, Brenda Leach and Arnon Lotem. 2003. "Helping Opportunities and Space Segregation in Cooperatively Breeding Cichlids.” Behavioral Ecology, 14 (6), 749-756. 
WeSTERn, Bruce. 1993. "Postwar Unionization in Eighteen Advanced Capitalist Countries." American Sociological Review, 58 (2), 266-282.

Wilkinson, David, Raymond Harbridge and Pat WaLSh. 2003. "Labour Market Re-Regulation and its Effects on Free Riding in New Zealand." Journal of Industrial Relations, 45 (4), 529-538.

Wilkinson, J., and M. BitTMan. 2002. Volunteering: The Human Face of

Democracy. SPRC Discussion Paper No. 114. Sydney: Social Policy

Research Centre, University of New South Wales.

WiLson, S., and T. Breusch. 2003. "Taxes and Social Spending: The Shifting

Demands of the Australian Public." Australian Journal of Social Issues, 38 (1), 39-56.

WynNe-EDWARDS, V. C. 1993. "A Rationale for Group Selection.” Journal of Theoretical Biology, 162 (1), 1-22.

Zappala, Giani. 1992. "Should Unions Support the Closed Shop?" What

Should Unions Do? M. Crosby and M. Easson, eds. Sydney: Lloyd Ross Forum, 296-315.

\section{RÉSUMÉ}

\section{Les valeurs coopératives, les institutions et le problème du resquillage en Australie : peut-on apprendre du Canada?}

La citoyenneté industrielle comporte à la fois des droits et des responsabilités pour les citoyens. Ceux-ci englobent le droit de participer à une activité collective, telle que la négociation et le besoin de se sentir responsable envers des membres d'une collectivité ou d'un groupe. Un des principaux problèmes inhérents à la coopération et à l'action collective est celui du resquillage, c'est-à-dire du fait de bénéficier des avantages d'une action collective sans apporter sa quote-part, plus précisément, en relations du travail, de bénéficier des avantages de la convention collective sans payer de cotisations syndicales. Cet essai traite des valeurs de la coopération, discute du problème du resquillage (free riding) et des changements institutionnels en Australie où, au cours des dernières années, ce problème a pris de l'ampleur. Il fait aussi ressortir le contraste avec le Canada, où la formule Rand a été introduite pour contrer le resquillage en relations du travail et cet arrangement pourrait fournir à l'Australie un modèle à imiter.

Le collectivisme renvoie à la façon dont les intérêts, les orientations et les comportements trouvent en grande partie leurs assises dans un groupe plutôt que dans les individus pris séparément. Les attitudes propres 
au collectivisme comprennent trois éléments principaux : la conscience d'une identité sociale commune, des valeurs de coopération partagées (ce qui est le sujet de cet essai) et un sens de l'efficacité collective (une croyance en un pouvoir) chez les membres d'un groupement. On peut concevoir les valeurs de coopération en termes de réciprocité et d'altruisme. Même si, pour quelques-uns, l'altruisme peut sembler un paradoxe, la théorie de l'évolution nous incite à penser qu'il est non seulement un important mécanisme de survie, mais aussi qu'il a joué un rôle clef dans l'évolution. Plus que beaucoup d'autres espèces, les humains reconnaissent les bienfaits d'un comportement coopératif. Alors qu'il existe une logique solide en faveur de la coopération, elle doit cependant faire face au sérieux problème que posent les resquilleurs, aussi appelés les parasites (free riders). Sans mécanisme pour les identifier et les punir, l'altruisme risque de disparaître. Il faut tenter d'atténuer cette forme de tricherie par l'adoption de lois et le développement d'institutions et de normes de comportement. Les groupements doivent trouver des façons de promouvoir la solidarité et de contrer le resquillage. La réponse habituelle des syndicats à cet égard consiste à s'assurer que tous ceux qui bénéficient des avantages de la syndicalisation en défraient les coûts. Un des grands défis des syndicats est donc celui de surmonter les tensions entre ce besoin de s'assurer que ceux qui reçoivent des avantages de l'action collective y contribuent équitablement, tout en évitant les malaises de l'adhésion syndicale obligatoire.

Il existe en général deux approches pour évaluer l'ampleur du resquillage. L'une d'elle utilise les données officielles pour comparer les évaluations de la densité syndicale et le champ d'application de la convention collective. L'autre approche consiste dans la conduite d'enquêtes auprès des salariés pour vérifier s'ils sont membres de l'unité syndicale et s'ils sont couverts par la convention collective (ou, du moins, s'il y a un syndicat auquel ils peuvent adhérer dans leur lieu de travail). Selon ces deux approches, les deux cinquièmes des salariés en Australie, assujettis à une convention collective, seraient des non-membres parasites, avec une pointe dans le secteur public, chez les femmes et chez les salariés dans des emplois atypiques ou à temps partiel. Le nombre de ces parasites se serait également accru au cours des dernières années.

Le contrôle des resquilleurs dépend de la présence soutenue de valeurs et d'institutions qui pourraient décourager ou empêcher un tel comportement. Est-ce que la croissance du resquillage signifie le déclin des valeurs coopératives et la montée de l'individualisme, ou encore est-elle le signe de changements institutionnels ? En Australie, même si ce n'est pas très évident dans l'imagerie populaire, il semble qu'en général les valeurs de l'individualisme ne sont pas préférées à celles de la coopération et il est 
fort possible qu'on se soit éloigné de l'individualisme au lieu de s'en être rapproché. En fait, un nombre croissant d'Australiens appuie les politiques de redistribution sociale. Pas plus qu'il n'existe une preuve d'un individualisme rampant, lorsqu' on considère plus particulièrement les attitudes à l'endroit des enjeux en relations industrielles, qui sont devenues plus favorables au syndicalisme au cours des dernières décennies. Dans la même foulée, on observe que le bénévolat s'est accru au cours des années 1990.

Les changements institutionnels rendent mieux compte du phénomène du resquillage. Les aménagements apportés à l'atelier syndical ont été rescindés au niveau fédéral et des provinces de façon à empêcher l'adhésion syndicale obligatoire ou la préférence syndicale. Ces lois ont contribué au déclin de l'effectif syndical de trois manières. En premier lieu, les recrues réfractaires n'ont plus à adhérer à un syndicat. En deuxième lieu, c'est devenu plus facile pour les entreprises de décourager l'appartenance à un syndicat. Enfin, le resquillage n'est plus restreint. En fait, parce qu'il n'existe plus de moyens chez les « coopérateurs » d'imposer des sanctions aux resquilleurs ou parasites, ces changements les ont plutôt encouragés. Les développements des années 1990 doivent être envisagés dans le contexte du rôle qu'ont joué les politiques de relations du travail à la frontière du conflit politique de classe en Australie. Plus qu'au Canada, les politiques en matière de relations industrielles ont connu un glissement radical au plan de la législation à cause d'une conscience plus aiguë de l'efficacité d'un changement législatif pour promouvoir un programme économique et politique.

La solution canadienne au problème des parasites a été l'adoption, dans les entreprises de juridiction fédérale et dans plusieurs juridictions provinciales, de ce qui est communément appelé la formule Rand (c'està-dire l'obligation faite à l'employeur, par la législation ou la convention collective, de déduire de la rémunération de tous les travailleurs d'une unité de négociation, qu'ils soient ou non membres du syndicat, un montant égal à la cotisation syndicale et de le remettre au syndicat ou, selon certaines juridictions, pour des motifs religieux, à une organisation charitable). La Cour suprême du Canada a statué que les dispositions de la formule Rand n'étaient pas incompatibles avec la Charte canadienne des droits et des libertés. Le problème du resquillage est ainsi devenu un enjeu mineur en train de disparaître au Canada. D'autres expériences à l'échelle internationale sont également instructives. L'Afrique du Sud a introduit la possibilité d'ateliers syndicaux en 1995. On retrouve ces derniers dans un certain nombre d'États américains. La représentation et la négociation collective ne sont pas les seules activités utilisant les ressources d'un syndicat; ainsi, de nombreuses décisions des cours de justice aux ÉtatsUnis imposent des limitations à l'usage des fonds amassés par le biais des aménagements d'ateliers syndicaux. 
En s'inspirant de la formule Rand, quelques syndicats australiens depuis la fin des années 1990 ont tenté d'introduire des droits d'entrée d'atelier dans les accords d'entreprise (au niveau d'une corporation ou d'un lieu de travail). Des syndicats ont essayé d'établir des droits d'entrée d'atelier à un taux plus élevé que celui des cotisations syndicales, leur conférant ainsi de ce fait l'apparence d'une forme de syndicalisation obligatoire. Ils se sont vus servir un traitement mitigé de la part des cours et des tribunaux, jusqu'à ce qu'ils soient éventuellement arrêtés par une loi et par un avertissement de la Cour supérieure.

Par delà les cotisations d'atelier, il peut être possible de concevoir des régimes qui viennent minimiser l'incitation à jouer aux parasites. L'un serait la permission d'inclure dans les conventions des cotisations de type « obligation sociale » : des dispositions qui exigeraient des salariés couverts par une convention collective de faire une contribution à une organisation volontaire au choix du salarié. Le montant de cette contribution devrait être fixé plus bas que celui des cotisations syndicales, reflétant ainsi les avantages privés qui s'accumuleraient chez les membres d'un syndicat. Ceci étant dit, on constate que le problème des resquilleurs reflète en grande partie la faiblesse du pouvoir syndical. En bout de ligne, les syndicats devront convaincre de leur pouvoir les membres éventuels; cela signifie qu'il faut appliquer de façon efficace les principes d'organisation syndicale. Avec la liberté du principe de non-adhésion ancrée dans le régime politique australien, des approches créatrices à la solution de ce problème de nonpaiement des cotisations sont nécessaires. 